\author{
Antoni Kolek \\ ORCID: 0000-0003-3315-1609
}

Społeczna Akademia Nauk, Wydział Zarządzania i Bezpieczeństwa

Oskar Sobolewski

ORCID: 0000-0003-3735-0891

Instytut Emerytalny

DOI: $10.19195 / 1733-5779.28 .24$

\title{
Pracownicze Plany Kapitałowe jako przykład zastosowania ekonomii behawioralnej
}

\section{JEL Classification: J32}

Słowa kluczowe: Pracownicze Plany Kapitałowe, PPK, ekonomia behawioralna, reforma emerytalna, emerytury, oszczędzanie,

Keywords: Employee Capital Plans, PPK, Behavioral economics, pension reform, pensions, saving

Abstrakt: Zmiany wprowadzane w obszarze długoterminowego oszczędzania w Polsce mają na celu stworzenie dodatkowych zasobów finansowych niezbędnych do pokrycia przyszłych potrzeb i zobowiązań. Funkcjonujące dotychczas produkty emerytalne wchodzące w skład III filaru systemu emerytalnego nie zyskały powszechności i nie zapewniają wystarczających środków na przyszłe świadczenia emerytalne. W celu przeciwdziałania dotychczasowym barierom rozwoju produktów długoterminowego oszczędzania zastosowano wiele rozwiązań wspierających wysoki poziom uczestnictwa w dobrowolnym, dodatkowym oszczędzaniu. Fundamentem aksjologicznym podjętych działań stało się pojęcie wolności, a teorią wyjaśniającą zachowania jednostek ekonomia behawioralna. W niniejszym opracowaniu przedstawiono mechanizmy zaczerpnięte $\mathrm{z}$ dorobku ekonomii behawioralnej, które zapisane zostały w ustawie z dnia 4 października 2018 roku o pracowniczych planach kapitałowych oraz aktach niższego rzędu konstytuujących system PPK w Polsce. W pierwszej części pracy przedstawione zostały przyczyny wprowadzenia nowego rozwiązania długoterminowego oszczędzania. W drugiej części pracy wskazano praktyczne zastosowania ekonomii behawioralnej wykorzystane w konstrukcji PPK. Pracę wieńczy krytyczne podsumowanie, wskazujące wyzwania i problemy, które mogą stanowić bariery w upowszechnieniu się tej formy oszczędzania. 


\title{
Employee Capital Plans as an example of behavioral economy implementation
}

\begin{abstract}
The changes introduced in the area of long-term savings in Poland are aimed at creating additional financial resources necessary to cover future needs and obligations. Previously functioning pension products included in the third pillar of the pension system have not become popular and do not provide sufficient funds for future retirement benefits. In order to counteract the existing barriers to the development of long-term saving products, a number of solutions supporting a high level of participation in voluntary, additional savings were applied. The axiological foundation of the actions undertaken became the notion of freedom and the theory explaining the behavior of individuals in behavioral economics. This study presents the mechanisms taken from the heritage of behavioral economics, which were recorded in the Act of 4 October 2018 on employee capital plans and lower-level acts constituting the PPK system in Poland. The first part of the work presents the reasons for introducing a new long-term saving solution. In the second part, the work contains a description of the duties of employing entities and the rights of participants of the Employee Capital Plans. In the third part of the work, practical applications of behavioral economics used in the construction of PPK were indicated. The work is crowned with a critical summary showing the challenges and problems that may constitute barriers to the spread of this form of saving.
\end{abstract}

\section{Przyczyny wprowadzenia Pracowniczych Planów Kapitałowych}

Pomysł wprowadzenia Pracowniczych Planów Kapitałowych pojawił się na początku lipca 2016 roku. Debata o wdrożeniu nowego rozwiązania długoterminowego oszczędzania, jaką staną się PPK, rozpoczęła się, kiedy ZUS przeprowadzał przegląd systemu emerytalnego, którego jednym z tematów była analiza systemu dobrowolnego i dodatkowego oszczędzania na emeryturę. Warto podkreślić, że propozycja utworzenia PPK pojawiła się, zanim ZUS opracował podsumowanie przeglądu $\mathrm{w}$ ramach zielonej i białej księgi ${ }^{1}$. Niewątpliwie jedną z najważniejszych przyczyn wprowadzenia PPK są prognozy demograficzne, które wskazują, że polskie społeczeństwo jest jednym z najszybciej starzejących się w Europie. W perspektywie roku 2060 praktycznie podwoi się liczba osób w wieku 70+ w stosunku do roku 2015. Ponadto liczba Polaków zmniejszy się o prawie $14 \%$ i osiągnie nieco ponad $33 \mathrm{mln}$ obywateli w stosunku do $38,5 \mathrm{mln}$ w roku 2015. Największym wyzwaniem dla systemu emerytalnego będzie grupa osób w wieku poprodukcyjnym. Kohorta osób, które będą pracowały, zmniejszy się w 2060 roku o 6,7 mln w stosunku do roku 2015. Odpływ zasobów ludzkich z tej grupy będzie determinował konieczność znalezienia źródeł dodatkowego finansowania emerytur i świadczeń o charakterze emerytalnym. W pierwszych założeniach PPK miały być formą dodatkowego świadczenia, którego wypłacanie miało zostać powiązane z osiągnieciem wieku emerytalnego bądź nabyciem uprawnień emerytalnych. W listopadzie 2017 roku, kiedy zaprezentowano pierw-

${ }^{1}$ G. Uścińska, K. Berrahal, A. Kolek, Przeglad emerytalny 2016 - bezpieczeństwo dzięki odpowiedzialności, „Polityka Społeczna” 2016, nr 1, s. 2-6.

Studenckie Prace Prawnicze, Administratywistyczne i Ekonomiczne 28, 2019

(C) for this edition by CNS 
sze oficjalne założenia do projektu ustawy o PPK, wycofywanie środków zostało uzależnione od nabycia uprawnień emerytalnych. To był ostatni projekt, w którym można było nazywać PPK świadczeniem o charakterze emerytalnym. Jednak projektodawca w projekcie przedstawionym do konsultacji społecznych w lutym 2018 roku zdecydował się na zapisanie możliwości wycofywania środków (zakończenie etapu akumulacji) od 60 roku życia zarówno dla kobiet, jak i dla mężczyzn. Zmiana ta spowodowała, że PPK straciły ostatni element charakteru emertytalnego. Takie określenie warunków nabycia prawa do świadczeń powoduje, że wielu uczestników PPK będzie miało możliwość wypłacenia swoich środków ( z PPK) jeszcze na etapie pracy (mężczyźni mogą rozpocząć wycofywanie swoich środków w wieku 60 lat, przy ustawowym wieku emerytalnym 65 lat).

Umownie nazwany III filar systemu emerytalnego w 2019 roku składa się z trzech produktów - dwóch indywidualnych (IKE i IKZE) oraz grupowego PPE. Od 2005 do 2015 roku PPE zostały utworzone przez niespełna 1,5 tys. podmiotów, z czego funkcjonujących PPE było nieco ponad tysiąc.

Prowadzone przez blisko dwa lata prace nad kształtem PPK znalazły swój finał w październiku 2018 roku, gdy ustawa została uchwalona przez Sejm. Natomiast 1 stycznia 2019 roku weszła w życie. Uchwalona ustawa mimo tak długiego procesu konsultacji i analiz wewnątrzresortowych i międzyresortowych jest niestety niedopracowanym aktem prawnym, który w zderzeniu z praktyką w wielu miejscach nie odpowiada na potrzeby wsparcia systemu emerytalnego. Jak wspomniano PPK mimo swoich pierwotnych zapowiedzi nie jest programem o charakterze emerytalnym, w związku z tym nie odpowiada na potrzeby uzupełnienia przyszłych emerytur. Nie zostały więc spełnione najważniejsze cele, jakie pomysłodawcy stawiali sobie, analizując problemy i wyzwania związane z systemem emerytalnym w Polsce.

Ostatnie 15 lat oszczędzania w III filarze emerytalnym pokazuje, że Polacy nie są zainteresowani dodatkowym oszczędzeniem na emeryturę. Łącznie zgromadzono ponad 23 mld zł w PPE, IKE i IKZE, warto jednak podkreślić, że wynik ten na koniec 2018 roku będzie większy, albowiem w wypadku aktywów PPE cały czas oficjalnie dostępne dane podają ich wartość na koniec 2017 roku, natomiast co do indywidualnych form mamy już dane z końca 2018 roku.

Najwięcej aktywów zgromadziły PPE, zgodnie z danymi KNF na dzień 31 grudnia 2017 roku było to niespełna 13 mld zł. Biorąc pod uwagę, że na ten dzień w PPE oszczędzało aktywnie około 310 tysięcy uczestników, to średnio każdy z nich zgromadził około 40 tys. zł. Gdyby takie aktywa zgromadziła większość pracowników, byłoby to widoczne uzupełnienie emerytury z III filaru, niestety PPE objęły tylko niecałe 3\% pracowników. To pokazuje, że jedyna trzyfilarowa forma dobrowolnego oszczędzania na emeryturę nie rozwinęła się dostatecznie i nadal stanowi tylko benefit na rynku pracy, a nie realne źródło środków na okres po 60 roku życia. 
Indywidualne formy, to jest IKE i IKZE, zgromadziły na koniec 2018 roku łącznie 11 mld zł, co stanowi niespełna połowę środków zgromadzonych w III filarze. Dane dotyczące aktywów w IKE i IKZE są dobrym odzwierciedleniem podejścia Polaków do dodatkowego oszczędzania na emeryturę. W przypadku IKE i IKZE decyzje o dobrowolnym oszczędzaniu podejmuje oszczędzający bez udziału pracodawcy, to oznacza, że wyłącznie pracownik decyduje, czy i w jakim stopniu oszczędzać. Informacje przekazywane przez przedstawicieli instytucji finansowych potwierdzają, że Polacy oszczędzają incydentalnie, raz ewentualnie kilka razy w roku, a tylko w niewielu sytuacjach robią to regularnie w każdym miesiącu. Taką tendencje najlepiej widać w kwestii wpłat na IKZE — większość osób zasila swoje konta w ostatnim kwartale roku kalendarzowego, tak żeby wpłacić limit przed 31 grudnia i móc skorzystać z odliczenia tej kwoty podczas rocznego rozliczenia z urzędem skarbowym.

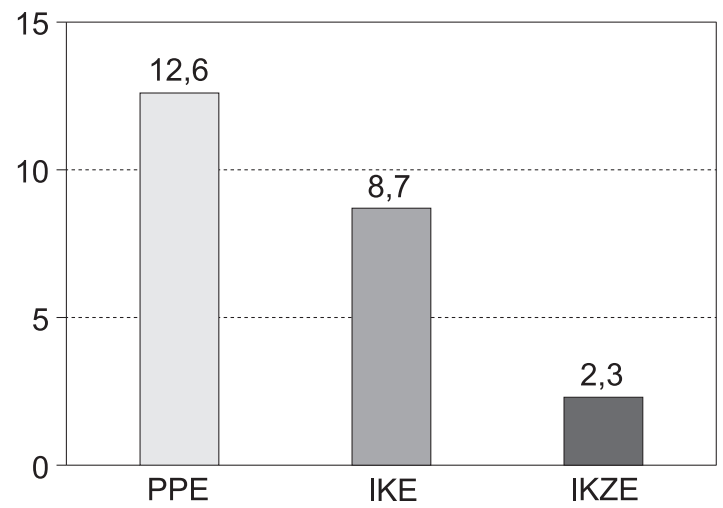

Wykres 1. Aktywa PPE na dzień 31 grudnia 2017 i aktywa IKE i IKZE na dzień 31 grudnia 2018 (mld zł)

Źródło: opracowanie własne na podstawie danych z KNF.

\section{Mechanizmy Pracowniczych Planów Kapitałowych będące wynikiem ekonomii behawioralnej}

Konstrukcja sytemu Pracowniczych Planów Kapitałowych opiera się na rozwiązaniach dorobku ekonomii behawioralnej. Biorąc pod uwagę, że polityka publiczna jako działalność praktyczna ma na celu rozwiązywanie problemów publicznych oraz sprzyjanie rozwojowi społeczno-gospodarczemu, za podstawowe narzędzie polityki publicznej należy uznać interwencję publiczną ${ }^{2}$. Takie podejście determinuje konieczność wzięcia pod uwagę i przeanalizowania skupionej wokół zagadnienia „interwencji”. Przedstawiciele nauk społecznych, podejmujący

2 R. Chrabąszcz, M. Zawicki, Nauki o polityce publicznej, [w:] Wprowadzenie do nauk o polityce publicznej, red. M. Zawicki, Warszawa 2014, s. 67. 
temat interwencji, często wskazują, że istotą interwencji publicznej jest zmiana dotychczasowych zachowań jednostek lub zbiorowości. Przez zmianę zachowania ma zostać rozwiązany dany problem publiczny, a sama zmiana nie powinna naruszać innych wolności i praw jednostki ${ }^{3}$.

Wobec problemu braku oszczędności emerytalnych Polaków, a także nieprzejawiania skłonności do systematycznego oszczędzania władze podjęły decyzję o wprowadzeniu Pracowniczych Planów Kapitałowych, opierając się na dorobku ekonomii behawioralnej. Twórcy koncepcji behawioralnego ujęcia zachowań jednostki stwierdzają, że wybory ludzi zależą nie od racjonalnych przesłanek, ale od emocji, poglądów, przyzwyczajeń, a także błędów. Specyfika ludzkiego działania może prowadzić do znaczących odstępstw od racjonalnych zachowań, a podejmowane działania częściej będą opierać się na takich przesłankach, jak:

— niechęć do straty — w sytuacji gdy jednostka ma poczucie, że grozi jej utrata czegoś, co dotychczas posiadała, jest gotowa podjąć działania przeciwdziałająca stracie,

— tendencja do utrzymania status quo, wyrażona jako lęk przed zmianami i nowym,

— ramowanie — określanie możliwości wyboru i dostarczanie gotowych wskazówek do podjęcia określonej decyzji,

- kotwiczenie, czyli stwarzanie odruchowych i emocjonalnych powiązań przyczynowo-skutkowych między bodźcem a zachowaniem,

— dostępność - aby nie być zobowiązanym do poczynienia znaczących działań jednostka jest skłonna podjąć decyzję obarczoną mniejszymi kosztami pośrednimi,

— reprezentatywność — wyrażająca efekt stadny i podążanie za modą, wpływem autorytetu czy przekonaniem o tendencji,

— optymizm i zbytnią pewność siebie - dającą się ująć w przekonaniu, że zawsze będzie tak, jak jednostka chce, żeby było ${ }^{4}$.

Należy w tym miejsce wskazać, że mechanizmy zawarte w regulacjach kształtujących Pracownicze Plany Kapitałowe zostały wprowadzone świadomie i władze celowo oddziałują na elementy systemu długoterminowego oszczędzania.

Pierwszym mechanizmem, nad którym warto się zastanowić, jest odciążenie osoby zatrudnionej od obowiązków administracyjnych, w tym obowiązku zapisywania się do programu długoterminowego oszczędzania. Zgodnie z postanowieniami ustawy z dnia 4 października 2018 roku o pracowniczych planach kapitałowych obowiązek utworzenia PPK leży po stronie podmiotu zatrudniającego,

3 S. Datta, S. Mullainathan, Behavioral Design. A New Approach to Development Policy, „CGD Policy Paper” 16, 2012, s. 1-33.

${ }^{4}$ R. Thaler, C. Sunstein, Impuls. Jak podejmować właściwe decyzje dotyczace zdrowia, dobrobytu i szczęścia, Poznań 2017, s. 133. 
który w odpowiednim terminie, zależnym od liczby zatrudnionych, będzie musiał wybrać instytucję finansową, a następnie wdrożyć PPK w swojej firmie 5 .

Co więcej, zgodnie z regulacjami kształtującymi PPK osoby zatrudnione w wieku 18-55 lat, których okres zatrudnienia w danym podmiocie zatrudniającym wynosi co najmniej trzy miesiące, do PPK zostaną zapisane automatycznie. $\mathrm{W}$ ich imieniu i na ich rzecz podmiot zatrudniający zawrze umowę o prowadzenie PPK, której stronami będą uczestnik PPK i instytucja finansowa. Oznacza to, że osoby te nie będą musiały wykazać się żadną aktywnością, aby zacząć oszczędzać w PPK. Z kolei osoby w wieku 55-70 lat będą mogły przystąpić do PPK na swój wniosek złożony pracodawcy. Zabieg ten ma na celu stworzenie świadomego wyboru dla osób, które mają najbliżej do emerytury, tak by same zdecydowały, co będzie dla nich najlepszą formą zabezpieczenia oszczędności ${ }^{6}$. Co ważne, grupa osób, które będą mogły uczestniczyć w PPK, została zdefiniowana szerzej niż jedynie pracownicy i do oszczędzania w PPK dopuszczeni zostali także objęci obowiązkowo ubezpieczeniem społecznym zleceniobiorcy, osoby wykonujące pracę nakładczą, członkowie rolniczych spółdzielni produkcyjnych, a także członkowie rad nadzorczych, pobierający za swoją pracę oskładkowane wynagrodzenie ${ }^{7}$.

Kolejnym aspektem ułatwienia oszczędzania w PPK jest obowiązek naliczania, pobierania i przekazywania wpłat przez podmiot zatrudniający do instytucji finansowej zarządzającej środkami uczestników PPK. Celem tego działania jest systematyczność oszczędzania i brak obowiązków po stronie samych uczestników. Uczestnik PPK nie przelewa środków do instytucji finansowej, nie musi pamiętać o terminach ani obliczać określonej wysokości środków przekazywanych do PPK. Takie administracyjne odciążenie ma sprawić, że uczestnicy PPK, którzy domyślnie zostaną zapisani, nie będą musieli podejmować działań związanych z bieżącą obsługą PPK.

Ponadto wprowadzenie mechanizmu współfinansowania oszczędności, w którym udział biorą uczestnik PPK — odprowadzający $2 \%$ swojego wynagrodzenia ${ }^{8}$, podmiot zatrudniający - dokładający 1,5\% wynagrodzenia oraz ze środków publicznych poprzez finasowanie wpłaty powitalnej w wysokości $250 \mathrm{zł}$ i dopłaty rocznej wynoszącej $240 \mathrm{zł}$, ma przyczynić się do rzeczywistego wzrostu zgromadzonych środków ${ }^{9}$. Ustawodawca dopuścił także możliwość większych wpłat do PPK poprzez wprowadzenie wpłaty dodatkowej uczestnika do $2 \%$, a także wpłaty dodatkowej podmiotu zatrudniającego — do 2,5\% wynagrodzenia.

${ }^{5}$ Ustawa z dnia 4 października 2018 roku o pracowniczych planach kapitałowych (Dz.U. z 2018 r. poz. 2215), art. 134.

${ }^{6}$ Dz.U. z 2018 r. poz. 2215, art. 14-15.

7 Dz.U. z 2018 r. poz. 2215, art. 2 pkt 18.

8 Ustawa z dnia 4 października 2018 roku o pracowniczych planach kapitałowych (Dz.U. z 2018 r. poz. 2215), art. 27.

9 Dz.U. z 2018 r. poz. 2215, art. 31-32. 
Istotnym z perspektywy partycypacji w PPK mechanizmem jest możliwość obniżenia wpłaty podstawowej, dokonywanej przez uczestnika planu kapitałowego. Gdy wynagrodzenie brutto uczestnika PPK nie przekracza kwoty równej 1,2-krotności minimalnego wynagrodzenia, o którym mowa w art. 2 ustawy z dnia 10 października 2002 roku o minimalnym wynagrodzeniu za pracę ${ }^{10}$, uczestnik będzie miał prawo złożyć deklarację o obniżeniu wpłaty do 0,5\%. Przy czym sam będzie obowiązany określić wysokość wpłaty. Mechanizm ten skuteczny będzie w każdym miesiącu, gdy wynagrodzenie osoby zatrudnionej nie przekroczy wskazanego limitu. Za weryfikację osiągnięcia limitu 1,2-krotności odpowiedzialność ponosi podmiot zatrudniający, jednak gdy uczestnik PPK skorzysta z tego uprawnienia pomimo przekroczenia limitu, poniesie sankcję w postaci niedopłaty rocznej 240 zł z Funduszu Pracy.

Warto także zauważyć, że dobrowolność uczestnictwa w PPK będzie miała charakter determinujący konieczność odnawiania deklaracji o rezygnacji. Celem tego mechanizmu jest zapisane do PPK osób, które z jakichś powodów złożyły w przeszłości deklarację o rezygnacji i bez dodatkowego (cyklicznego co cztery lata) bodźca nie rozpoczęłyby oszczędzania.

Wobec tego ustawodawca nałożył na podmiot zatrudniający obowiązek ponownego zapisania do PPK wszystkich zatrudnionych, którzy wystąpili z Planu. Co cztery lata, począwszy od lutego 2023 roku, podmiot zatrudniających będzie miał obowiązek poinformować (do końca lutego) wszystkich, którzy zrezygnowali z oszczędzania i są w wieku poniżej 55 lat, że jeżeli nie otrzyma ponownie deklaracji o rezygnacji, to od 1 kwietnia 2023 roku osoby te staną się uczestnikami PPK poprzez zawarcie w ich imieniu i na ich rzecz umowy o prowadzenie PPK ${ }^{11}$.

Zastosowanie mechanizmów ekonomii behawioralnej nie oznacza jednak zupełnego porzucenia dotychczas stosowanych narzędzi i motywatorów. Pracownicze Plany Kapitałowe zakładają zwolnienie z danin publicznych zarówno na etapie akumulacji, jak i po osiągnięciu 60 roku życia. Warto podkreślić, że wpłaty dokonywane do PPK zwolnione są ze składki na ubezpieczenia społeczne. Ponadto środki gromadzone w PPK są wolne od zajęć i egzekucji komorniczych (wyjątek stanowią zajęcia ze względu na alimenty), co ma stanowić o ochronie środków ${ }^{12}$. Ustawodawca zdecydował także o domyślnej formie wypłaty zgromadzonych środków, wskazując, że brak potrąceń (podatków i składek) będzie następował, jeśli uczestnik zdecyduje się na jednorazową wypłatę środków w wysokości nie wyższej niż 25\% zgromadzonych oszczędności, a pozostałe $75 \%$ zostanie roz-

10 Ustawa z dnia 10 października 2002 roku o minimalnym wynagrodzeniu za pracę (Dz.U. z 2017 r. poz. 847; oraz z 2018 r. poz. 650), art. 2.

11 Ustawa z dnia 4 października 2018 roku o pracowniczych planach kapitałowych (Dz.U. z 2018 r. poz. 2215), art. 23.

12 Dz.U. z 2018 r. poz. 2215, art. 94. 
łożone na co najmniej 120 miesięcznych rat. Mechanizm ten ma zniechęcać do wcześniejszego wycofania środków.

W celu mitygowania tak zwanego ryzyka złej daty, gdy uczestnik programu emerytalnego tuż przed nabyciem prawa do świadczenia lokuje swoje aktywa w ryzykownych instrumentach finansowych, ustawodawca zdecydował się wprowadzić precyzyjne ramy polityki inwestycyjnej. Każdy uczestnik PPK zostanie zapisany do Funduszu Zdefiniowanej Daty właściwego jego wiekowi i dacie osiągnięcia 60. roku życia. Każdy z funduszy będzie odznaczał się specyficzną polityką inwestycyjną, adekwatną do wieku uczestnika. Co ważne, Fundusz Zdefiniowanej Daty będzie mógł lokować środki uczestników w instrumenty udziałowe i dłużne w proporcji pozwalającej na zabezpieczenie wartości zgromadzonych środków. Oznacza to, że dostosowując się do wieku uczestnika PPK, Fundusz będzie lokował więcej środków w części dłużnej, tak by ograniczyć ryzyko inwestycyjne ${ }^{13}$. Uczestnik PPK będzie mógł zmienić fundusz, w którym gromadzi środki, a stosowna dyspozycja powinna być przekazana do instytucji finansowej.

Warto także podkreślić, że uczestnik PPK będzie mógł skorzystać ze zgromadzonych środków jeszcze przed osiągnięciem 60 roku życia. Ustawa o pracowniczych planach kapitałowych przewiduje możliwość wypłaty na etapie akumulacji w czterech przypadkach:

- wypłata transferowa, czyli przekazanie 100\% zgromadzonych środków na inny rachunek PPK albo inny rachunek uczestnika związany z długoterminowym oszczędzaniem ${ }^{14}$,

- w przypadku poważnego zachorowania uczestnik PPK będzie miał prawo do wypłaty do $25 \%$ zgromadzonych środków w przypadku zdiagnozowania u uczestnika, jego małżonka lub dziecka uczestnika określonej jednostki chorobowej lub całkowitej niezdolności do pracy czy umiarkowanego lub znacznego stopnia niepełnosprawności ${ }^{15}$,

- w celu pokrycia wkładu własnego w związku z ubieganiem się o kredyt hipoteczny na zakup nieruchomości uczestnik PPK będzie mógł uzyskać pożyczkę do 100\% zgromadzonych środków na rachunku PPK, która przeznaczona zostanie na pokrycie wkładu własnego; należy jednak pamiętać, że możliwość skorzystania $\mathrm{z}$ tej formy wypłacenia środków będzie tylko do 45 roku życia uczestnika PPK i będzie się wiązała $\mathrm{z}$ obowiązkiem oddania środków na rachunek ${ }^{16}$,

— zwrot — w każdej chwili uczestnik PPK będzie mógł wycofać 100\% zgromadzonych w PPK środków, jednak przed otrzymanie środków instytucja finan-

13 Dz.U. z 2018 r. poz. 2215, art. 27.

14 Dz.U. z 2018 r. poz. 2215, art. 102.

15 Ustawa z dnia 4 października 2018 roku o pracowniczych planach kapitałowych (Dz.U. z 2018 r. poz. 2215), art. 101.

16 Dz.U. z 2018 r. poz. 2215, art. 98. 
sowa dokona stosownych potrąceń danin publicznych oraz przekaże środki pochodzące z wpłaty powitalnej i dopłat rocznych do Funduszu Pracy ${ }^{17}$.

Postanowienia ustawy z dnia 4 października 2018 roku o pracowniczych planach kapitałowych zawierają także katalog sankcji za nieprzestrzeganie obowiązków, a także nierealizowanie ustawowo określonych założeń. Jedną z podstawowych regulacji jest zakaz nakłaniania do rezygnacji z oszczędzania w PPK. Ustawodawca wskazał, że podmiot zatrudniający lub osoby działające w jego imieniu zniechęcające do udziału w PPK narażają się na sankcję w wysokości 1,5\% funduszu wynagrodzeń za poprzedni rok obrotowy. Sankcja ta będzie udzielana w postaci grzywny nakładanej przez Państwową Inspekcję Pracy.

Przytoczone mechanizmy mają na celu odciążenie administracyjne uczestników PPK oraz domyślne zapisanie osób które z jakichś powodów złożyły w przeszłości deklarację o rezygnacji zatrudnionych do oszczędzania w PPK, a także domyślne pokierowanie polityką inwestycyjną PPK. Różnorodność możliwości zadecydowania o wysokości odprowadzanych wpłat do PPK, możliwość wcześniejszego wycofania środków, a także prywatny charakter oszczędności w PPK mają zachęcić osoby zatrudnione do pozostania w PPK, a osoby w wieku 55-70 lat do dobrowolnego zapisania się do planu kapitałowego prowadzonego w danym podmiocie zatrudniającym.

\section{Krytyczne podsumowanie}

Konieczność zbudowania oszczędności polskich gospodarstw domowych jest tematem często pojawiającym się w debacie publicznej. Głos w dyskusji zabierają zarówno naukowcy, politycy, jak i przedstawiciele związków zawodowych i przedstawiciele pracodawców. Istotną sporu nie jest, czy państwo powinno wspierać oszczędności Polaków, ale w jaki sposób państwo powinno stymulować budowę oszczędności gospodarstw domowych. Odpowiedzią władz publicznych na problem niskiego poziomu oszczędności oraz perspektywy świadczeń emerytalnych, których wysokość nie pozwoli na zaspokojenie potrzeb i aspiracji, powinno być wprowadzenie powszechnego rozwiązania długoterminowego oszczędzania. Warto zauważyć, że ograniczenie stosowania PPK do osób zatrudnionych wyklucza osoby prowadzące pozarolniczą działalność gospodarczą, przedstawicieli służb mundurowych czy rolników.

Wydaje się także, że etapowość rozwiązania przyjęta pod względem liczebności podmiotu zatrudniającego nie jest sprawiedliwa w stosunku do osób pracujących w jednostkach sektora finansów publicznych, które w PPK zaczną oszczędzać dwa lata później niż pracownicy największych firm.

Bez wątpienia największym wyzwaniem dla twórców sytemu PPK jest poziom partycypacji w PPK. Wydaje się, że wprowadzenie wpłaty podstawowej uczestni-

17 Dz.U. z 2018 r. poz. 2215, art. 105. 
ka PPK na poziomie 2\% może stanowić znaczący wydatek dla osób zatrudnionych i być przyczyną rezygnacji z oszczędzania. Można przepuszczać, że niższa wpłata do PPK i stopniowe jej podnoszenie byłoby skuteczniejszym bodźcem pozostania lub przystąpienia do PPK.

Warto, aby uczestnicy PPK oprócz samego oszczędzania w ramach planu kapitałowego zyskiwali wiedzę o produktach długoterminowego oszczędzania oraz możliwościach dodatkowego gromadzenia środków. W tym celu ustawodawca powinien położyć większy nacisk na obowiązki informacyjne, cykliczne sprawozdania instytucji finansowych oraz działania pracodawców, którzy produkt PPK powinni wbudować w system benefitów pracowniczych w firmie.

Nie ulega wątpliwości, że połowa 2019 roku to dopiero start Pracowniczych Planów Kapitałowych i szansa na rozwój dodatkowego oszczędzania w Polsce. To, czy zastosowane przez ustawodawcę mechanizmy zaczerpnięte $z$ ekonomii behawioralnej sprawdziły się przy wdrożeniu PPK, będzie można oceniać przez pryzmat partycypacji najwcześniej po roku funkcjonowania PPK.

\section{Bibliografia}

Bielawska K., Skutki finansowe odwrotu od reformy emerytalnej z 1999 r. dla Funduszu Ubezpieczeń Społecznych, [w:] Dylematy teorii i praktyki ubezpieczeń, red. W. Sułkowska, G. Strupczewski, Warszawa 2015.

Dybał M., Charakterystyka wybranych systemów emerytalnych, [w:] Adekwatność dochodowa, efektywność i redystrybucja $w$ systemach emerytalnych: ujęcie teoretyczne, metodyczne i empiryczne, red. F. Chybalski, Warszawa 20161.

Jakubowski S., Funkcje subkonta ZUS a uwarunkowania prawne, „Rozprawy Ubezpieczeniowe. Konsument na rynku usług finansowych" 2018, nr 27.

Jedynak T., Ryzyko starości a dodatkowy system emerytalny w Polsce, „Zeszyty Naukowe, Uniwersytet Ekonomiczny w Krakowie” 2016, nr 8 (956).

Jędrasik-Jankowska I., Pojęcia i konstrukcje prawne ubezpieczenia społecznego, Warszawa 2018.

Kahneman D., Thinking, fast and slow, New York 2018.

Kolek A., Behawioralne interwencje publiczne — zatożenia, metody i znaczenie dla polityki publicznej, [w:] G. Uścińska, B. Samoraj-Charitonow, A. Kolek, Metodologia badań nauk o polityce publicznej w obszarze zabezpieczenia społecznego, Warszawa 2016.

Kolek A., Sobolewski O., Wojewódka M., PPK w firmie. Tworzenie, obowiazki informacyjne, rozliczanie wplat, Warszawa 2019.

Kolek A., Sobolewski O., Wojewódka M., Pracownicze Plany Kapitałowe — kompendium dla podmiotów zatrudniajacych, Warszawa 2018.

Kolek A., Wojewódka M., Pracownicze Plany Kapitałowe — szansa czy miraż?, Warszawa 2017.

Pacud R., Sprawiedliwość w prawie emerytalnym. Kwestie międzypokoleniowe oraz ekonomiczne, „Annales Universitatis Mariae Curie-Skłodowska, Sectio G, Economia” 62, 2015, z. 2.

Thaler R.H., Benartzi, S., Save more tomorrow TM: Using behavioral economics to increase employee saving, „Journal of Political Economy” 2004, 112 (S1).

Thaler R.H., Sunstein C., Impuls. Jak podejmować właściwe decyzje dotyczace zdrowia, dobrobytu i szczęścia, Poznań 2017.

Uścińska G., Berrahal K., Kolek A., Przeglad emerytalny 2016 - bezpieczeństwo dzięki odpowiedzialności, „Polityka Społeczna” 2016, nr 1. 
Uścińska G., Samoraj-Charitonow B., Kolek A., Metodologia badań nauk o polityce publicznej w obszarze zabezpieczenia spolecznego, Warszawa 2016.

Walczak D., Pieńkowska-Kamieniecka S. (2015), Solidarity on the example of farmers' pension insurance in Poland, [w:] Agrarian Perspectives XXIV. Global Agribusiness and the Rural Economy, Proceedings of the 24th International Scientific Conference, Prague 20158.

\section{Employee Capital Plans as an example of behavioral economy implementation}

\section{Summary}

The challenges associated with the savings of Polish households is a topic that often appears in the public debate. Both scientists, politicians, as well as representatives of trade unions and employers' representatives take the floor in the discussion. An important dispute is not: "should the state support Poles' savings", but "how should the state stimulate the construction of household savings?". The response of public authorities to the problem of low level of savings and the prospects of pension benefits, the amount of which will not meet the needs and aspirations should be the introduction of a universal solution for long-term savings. It is worth noting that limiting the use of PPK to employed persons excludes persons who run non-agricultural business activities, representatives of uniformed services or farmers. 
Studenckie Prace Prawnicze, Administratywistyczne i Ekonomiczne 28, 2019 (C) for this edition by CNS 